\title{
Accessibility for all: going from theory to practice
}

\author{
Isabela Andrade ${ }^{\mathrm{a}}$, Vanessa Dorneles ${ }^{\mathrm{a}}$ e Vera Helena Moro Bins Ely ${ }^{\mathrm{a}}$ \\ a PósARQ, Curso de Arquitetura e Urbanismo, UFSC
}

\begin{abstract}
The present work demonstrates, through a case study, the importance of theoretical knowledge in practical application of spatial accessibility in order to guarantee equal conditions for all people in the movement and use of space. Initially there was a literature review on the accessibility of space and how design in a accessible way. Next, we show one makeover proposal in one public school that wants to provide access to people with disabilities. This makeover was done and so we could evaluate the buildings changes through the method of accompanied walk with two people. Finally we present the main results and discussions.
\end{abstract}

Keywords: spatial accessibility; accessible design; accompanied walk; people with disabilities, school

\section{Introdução}

The accessibility application in architecture design is very important. In Brazil, since 2004, all buildings must be accessible as required by Law. However, the reality is other, there are few initiatives with inclusive design in all country. One problem is the lack of training places to capacity professionals to design for inclusion and also to supervise new construction on terms of accessibility. Although professionals are graduated and able to design, they don't know how apply the accessible parameters in their projects exactly. Other important question is a large gap between study accessibility theory and know how used it to practice design. This paper's goal is to propose a reflection on accessibility theory and practice. For this, we show one makeover proposal for a municipal school that needs access adaptation and the use analyze of adapted spaces.

This case study can demonstrate tree design steps: the conception, the implementation and the evaluation.

With this is possible answer some questions about how design in a accessible way. After all, how act in makeovers cases? Which aspects should be considered in those cases? What criteria design is more relevant? What changes are still needed?

\section{Methods}

This paper presents a literature review about spatial accessibility and one case study. The case study consists in one proposal of accessible design to one school and its evaluation through the method accompanied walks developed by Dischinger (2000).

\section{Spatial Accessibility}

In architecture, accessibility can be considered more than spaces that can be used by all people equally. Dischinger, Bins Ely and Piardi (2009) define "spatial accessibility means much more than enter in desired place. It is also necessary that the place allows the user to understand its function, its organization and spatial relations, as well as participate in activities that occur there". The authors argue that these actions must be taken with safety, comfort and independence.

Is worth noting that, when we use universal accessibility solutions considering all needs possible, we can achieved spatial accessibility conditions that allows the participation of many people. 
Accessibility is design buildings, cities and products that can be used and appropriated with confort, security and autonomy for all people equally, regardless of their abilities or limitations.

To understand better the accessibility concept, it is important to know the conditions of access to information, communication, movement and use opportunities, to all people can participate of activities and so have their citizenship rights guaranteed according to what is provided in the Brasiliam Constitution in 1988.

\subsection{Spatial accessibility components}

Dischinger, Bins Ely e Piardi (2009) defined the Spatial Accessibility Componentes because they want to contribute with evaluation and supervision acts in public buildings. This components are divided in four categories: spatial orientation, communication, displacement and use. For this authors "each component consists in one guideline sets that define spatial characteristics to allow accessibility to public buildings and minimize the restrictions".

The spatial orientation is linked to the space understanding, i.e., when users can recognize the space functions and define their strategies for use and displacement. The orientation conditions depends on the architecture configuration and additional supports, like sighs and maps, add to individual conditions to make decisions and act.

The communication refers to the interpersonal exchange possibilities or the information exchange through assistive technology devices, enabling access, understanding and participation in all activities.

Displacement refers to the conditions of movement along the horizontal and vertical routes independently, safe and comfortable, uninterrupted and free of barriers.

The use is the participation possibility of everybody in all activities and can use all environments and equipment.

So to obtain spatial accessibility, it is necessary to understand the components totally, because when one of than is out of your design the others may also be affected.

\section{Designing in a accessible way}

All the architectural program is intended for use by people, and therefore, should aim to be as inclusive as possible to allow a universal accessibility.

However, for projects that are accessible, first there have to be qualified professionals that can design products and spaces considering human diversity. For this we need the technical knowledge on the subject is increasingly present in professional and academic activities in order to produce a critical sense and improving the design process as a whole.

For some authors, such as Heylighen and Bianchin (2010), this is only possible from an approximation of professionals with real users. Designers should seek to understand the user's needs through the interection with them or having consultants during the procces of design. In Brazil, eg, the public and urban decisions must be discuss with the population. In design, we can make meetings and workshops that bring together the diverse stakeholders in the design process (Heylighen and Bianchin 2010).

The work of Miyake (2001) in landscape architecture in Japan is a good example of this form of design. The author divides his design methodology in four steps:

- Research and analysis of the universal design needs: corresponds to a survey of population information, especially disabled and elderly (MIYAKE 2001);

- Proposal and Site Survey: In this stage the author seeks the best solution according to the data collected in the previous survey linked to the characteristics of the site (MIYAKE 2001);

- Verification by users: usability test is to check whether the design is suitable for people with different habilities (MIYAKE 2001);

- Feedback: is to add or modify the project and the survey data based on verification results (MIYAKE 2001).

This design methodology shows an ideal situation because there is the participation of users in the programming design stage and the user's collaboration in the final stage of the project, with the possibility of feedback and correction if necessary. 


\section{Case study - municipal school}

The school studied is located near to downtown in one city in west of Santa Catarina State in southern Brazil. Approximately 150 children attend this school, morning and afternoon.

The Education Municipal Department has requested a project to adapt the access ramp for disabled people and expand the computer lab and the refectory in this building. In addition, it was necessary that all areas would enable movement and use by any individual, regardless of their physical limitations

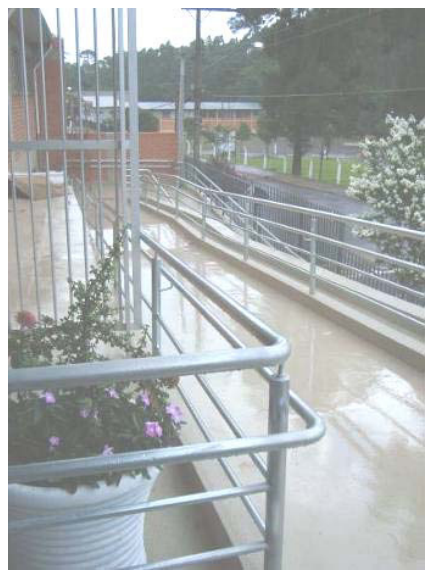

Figure 1: Main access to school by ramp. (ANDRADE, 2010)

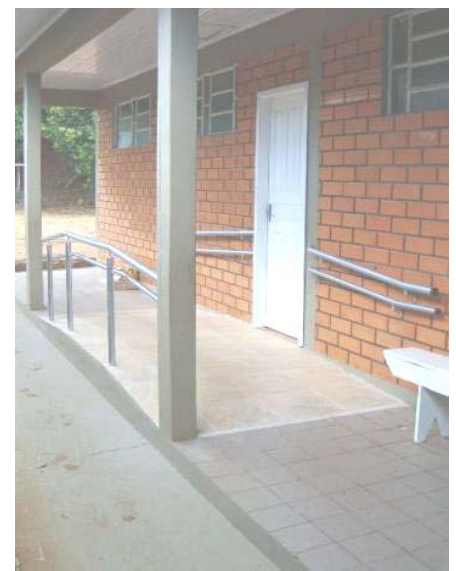

Figure 2: Acess to classroom by ramp, with handrails at two heights on both sides. (ANDRADE, 2010)

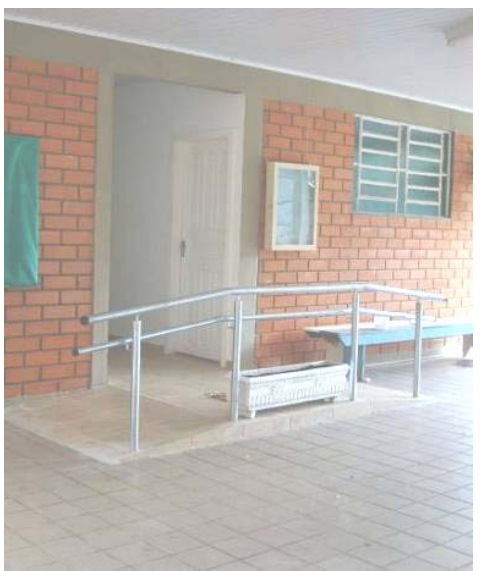

Figure 3: Ramp created to allow access in all public spaces, like secretary, teachers room, labs, library and toilets. (ANDRADE, 2010)
In the case of existing bathrooms, which were small, unable to adapt and were located next to the kitchen, we decided to turn them into the refectory. The new toilets have had their internal spaces designed according to accessibility standards (ABNT, 2004). In addition, teachers and staff also gained a new bathroom, large enough for use by people with disabilities.

As for the classroom, was created ramp that provides access to only one of them (Figure 02) because the funds for makeover was limited.

Public spaces such as dining room, kitchen, toilets, laboratories, library, office, living room and toward the teachers had access through ramps (Fig. 03) and there were changes in the internal circulation like improve layout and inclusion of appropriate furniture.
It should be noted that this adaptation of the school was conducted in a preventive way, since there are no students with disabilities using their premises for now.

\subsection{Proposal evaluation-acompanied walk}

To evaluate interventions occurred in the school we chose to use the method called Acompanied walk, developed by Dischinger (2000, p.50).

This method consists in visits to strategic locations for assessment together with people who may have difficulty in using the space or have some characteristic that is relevant to the search. Initially, the activities that respondents must meet are set. After a route is accomplished with the person and their behavior 
observed. The researcher asks questions concerning decision-making during the route.

According to Dischinger (2000), the researcher should not help or lead, it can only intervene in situations that present risks to the respondent. The whole conversation should be recorded to be written later. The main facts must be registered with the photography technique.

\subsubsection{Sample Characterization}

To obtain information about the access conditions into building studied, we choose a person without disabilities, but it has restrictions on the use of space: a mother with her baby using a baby carriage for displacement. This person was selected to present temporary difficulties of displacement and use of space because of the stroller.

\subsubsection{Experiment Development}

Initially, the activities script that should be developed has been defined, such as: to enter in school, to visit the office, to use the bathrooms, to visit the refectory, to visit the library and to visit two classrooms: one with access ramp and another with access by one step.

During the tours, we did observations of user behavior and questions regarding their perception of the environment and their decision-making (behavior and action), complementing the method. At the end of the tour, we did the following questions:

- What facilities are on your route?

- What are the difficulties encountered along the way?

- Do you use information signs to guide you?

- What did you like this building?

- What you do not like this building?

Before applying the method accompanied walk, the interviewee was transported by private car from his residence to the school. Before entering the building we explained the purpose of the tour and what would happen, we asked her to let us know all the difficulties and facilities identified in the route.

The accompanied walk lasted 50 minutes and occurred in the morning shift. The determination of the date and time was made according to the interviewee availability.

\subsubsection{Acompanied walk results}

The interviewee said she knew where the school was located. Arriving at the building, she identified the first problem: the access ramp, implanted to provide access to all, was closed (Figure 04).

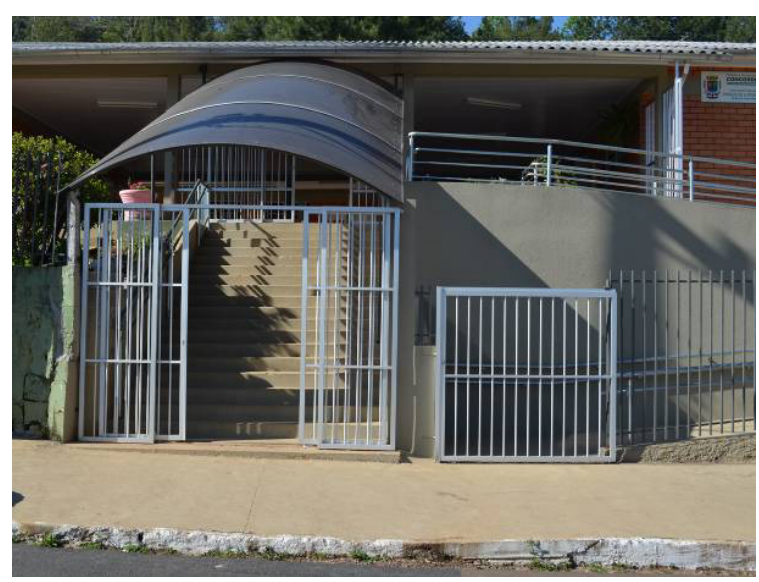

Figure 4: School Access - ramp access closed

To enter the space, she climbed the stairs of the school holding the stroller and baby (Figure 05). At this point she said that only won because the gap is used to raise the baby in the stroller every day in the building where she resides, where there is no elevator.

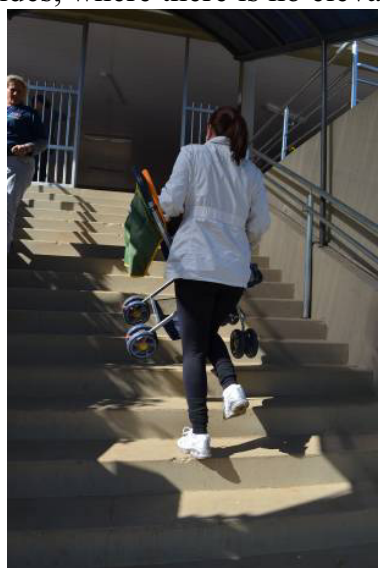

Figure 5: Mother had to carry the stroller on the stairs.

When she arrived at the school hall, she had no difficulty in locating access to the secretary, the school 
administration, library, computer lab and bathrooms. She said it was easy due to existing ramps (Figure 06).

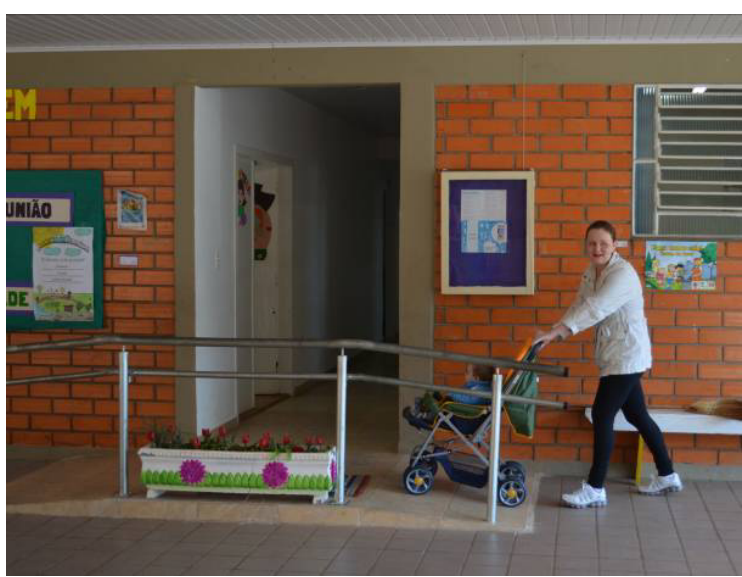

Figure 6: The interviewee walking on access ramps to the direction, secretary, computer lab and school bathrooms.

One of the activities proposed by the researchers was to find one bathroom, the Mother with baby had no difficulty in finding it. However, when she approached she said: "Must I enter here with the boy ?". (Figures $07 b$ and $07 a)$.

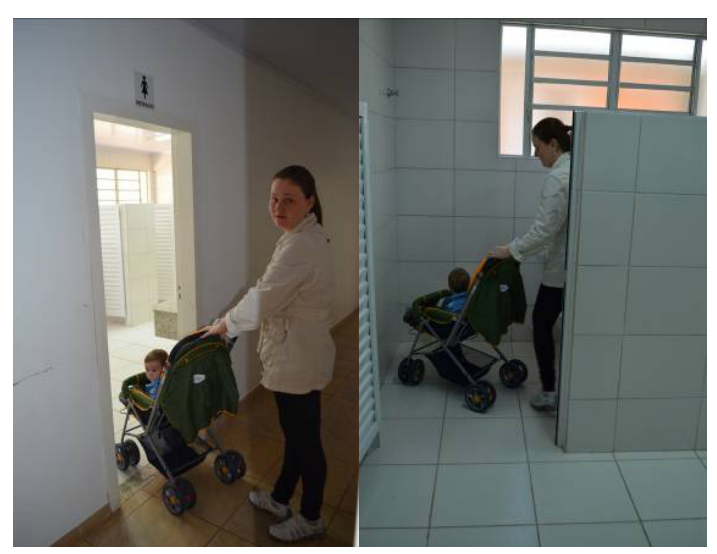

Figure 7a e 7b: Mother using accessible bathroom.

Following the respondent searched the school refectory, she got no problems to identify the space, enter and move inside (Figures 08a and 08b).

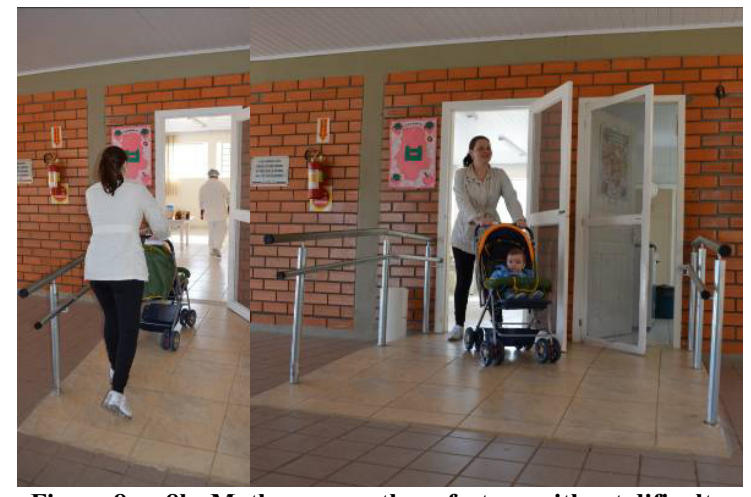

Figure 8a e 8b: Mother access the refectory without dificults. Ramp with handrails in two hights

As últimas atividades a serem executadas, localizar duas salas de aula, não foi difícil em relação a orientação no espaço, visto que há um bloco somente de salas de aula bem identificado através do zoneamento. Para chegar até ele a entrevistada passou por uma rampa com leve inclinação, inserida durante a reforma ocorrida em 2010 (figura 09).

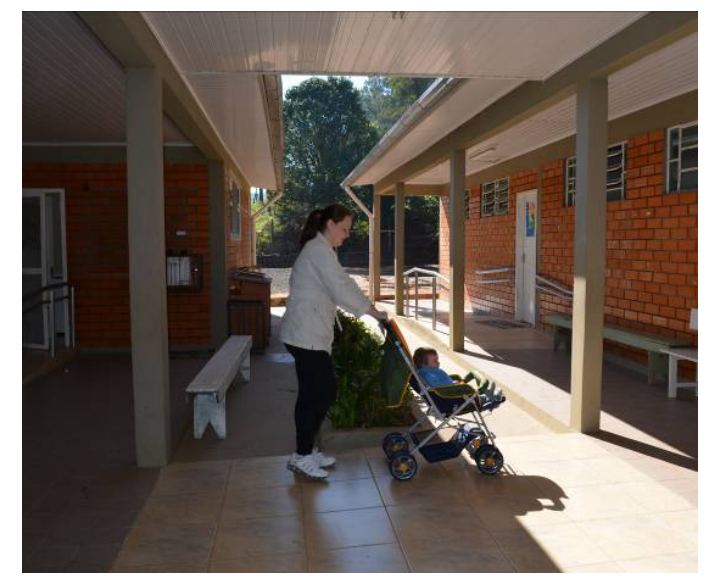

Figure 9: Mother with stroller accessing the class room

When she arrived in the room without access to the ramp, she expressed discomfort, saying that "a person without strength in his arms could not lift the stroller and walk into the room." On the other hand, she entered without difficulty in the classroom that had its access makeover through ramp (Figures 10a and 10b) 
she feels "safely" because in all ramps handrails were implanted in two heights.

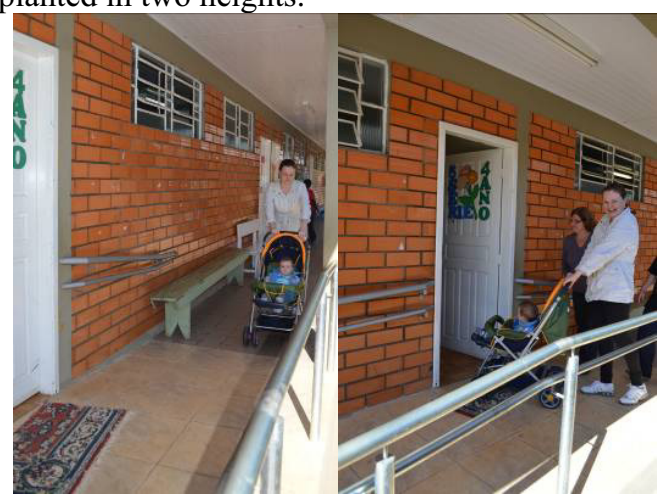

Figure 10a e 10b: Mother arriving in classroom by ramp.

At the end of the accompanied walk, some school staff informed that the ramp was liberated for use and the gate was open. Thus, the interviewee could leave the building with the stroller more comfortably (Figures $11 \mathrm{a}$ and $11 \mathrm{~b})$.

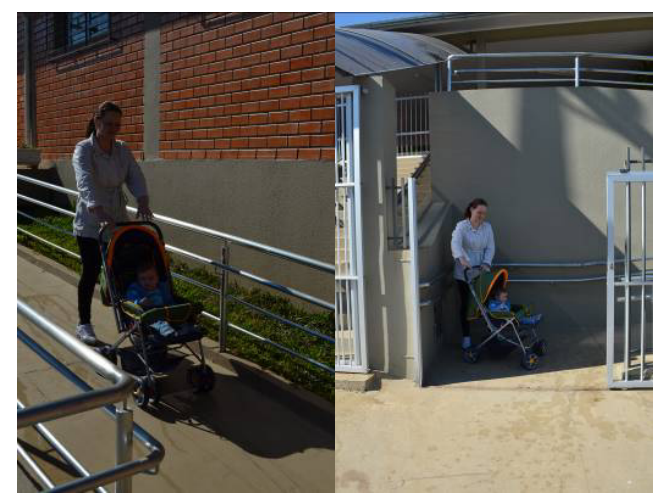

Figure 11a e 11b: Mother with stroller leavind the building by ramp.

At the end of the tour, we questioned her about the difficulties and facilities found. The mother praised the building, claiming that she usually finds it difficult to move with the stroller. However, she had no problems at this school, except the main entrance, because the gate with ramp access was closed and she needed to climb the stairs.

\section{Discussion}

This paper was able to develop one quick theoretical review about accessibility and how to design an accessible manner. Moreover, it presented one design example that aimed to makeover one school to make ir accessible.

Throughout the work we tried to have the user feedback regarding the use of adapted space and, thus, learn more about how making buildings more accessible.

Regardless of the adopted methodology by designers, the commom sense said that one project thought since its inception focusing on allow access for all, always is more efficient than one subsequent amendment. Because the existing spaces need new human resource and the development of new project outside ideal conditions to become accessible.

It can be argued that adjustments to existing schools are possible but often there are some deadlocks that impede the adaptation of all spaces, such as financial issues.

We believe that in cases of makeovers, the designers must first choose to solve the problems of displacement and use, eliminating the physical barriers that, as the acompanied walk done, can restrict the people participation in most activities. Later, the project should focus on solutions for the other accessibility components: information and communication.

It is noteworthy that, although it isn't possible to guarantee the optimum condition of accessible design in makeover cases, according the samples studied, is possible have good results to promote accessibility with the intervention.

\section{References}

[1] ABNT, A. B. D. N. T. 2004. NBR 9050/2004: Norma Brasileira de Acessibilidade a edificações, mobiliário, espaço e equipamentos urbanos., Rio de Janeiro.

[2] ANDRADE, Isabela Fernandes. 2010. Projeto de reforma (área $=577,18 \mathrm{~m}^{2}$ ) e ampliação (área-214,25 m²), especificação e orçamento de uma obra no G.E.M. Parque de Exposições, localizado no município de Concórdia-SC, Concórdia, CREA/SC: ART no $3727257-0$. 
[3] DISCHINGER, M. (2000). Designing for all senses: accessible spaces for visually impaired citizens. Thesis (for the degree of Doctor of Phiolosophy) Göteborg, Swe[den, Department of Space and Process School of Architecture, Chalmers University of Technology.

[4] DISCHINGER, M., BINS ELY, V. H. M. \& PIARDI, S. M. D. G. 2009. Promovendo a acessibilidade nos edifícios públicos: Programa de Acessibilidade às Pessoas com Deficiência ou Mobilidade Reduzida nas Edificações de Uso Público., Florianópolis, Ministério Público de Santa Catarina.

[5] GUIMARÃES, M. P. 2010. O ensino de design universal nas universidades. In: PRADO, A. R. D. A., LOPES, M. E. \& ORNSTEIN, S. W. (eds.) Desenho Universal: caminhos da acessibilidade no Brasil. São Paulo: Annablume.
[6] HEYLIGHEN, A. \& BIANCHIN, M. 2010. Can crap design be inclusive? In: Proceedings of the 5th Cambridge Workshop on Universal Access and Assistive Technology, . Cambridge (UK): Clarkson, P., Langdon, P., Robinson, P. (Eds.) Cambridge Workshop on Universal Acces And Assistive Technology.

[7] MIYAKE, Y. 2001. Chapter 48. Landscape Design. In: PREISER, W. F. E. \& OSTROFF, E. (eds.) Universal Design Handbook. New York: McGraw-Hill.

[8] PAULSSON, J. 2006. Universal Design Education, Gotenborg, EIDD Sverige \& NHR. 